\title{
Water quality of rivers in the eastern region of Cianorte (Paraná, Brazil) under relevant influence of industrial and agricultural waste
}

Qualidade da água dos rios da região leste de Cianorte (Paraná, Brasil) sob influência relevante de resíduos industriais e agrícolas

Calidad del agua de los ríos de la región oriental de Cianorte (Paraná, Brasil) bajo influencia relevante de residuos industriales y agrícolas

Received: 06/18/2021 | Reviewed: 06/25/2021 | Accept: 06/28/2021 | Published: 07/12/2021

Éderson Vecchietti Gonçalves

ORCID: https://orcid.org/0000-0001-6404-8167 Universidade Tecnológica Federal do Paraná, Brazil

E-mail: escliven@hotmail.com

Letícia Scala Frâncica

ORCID: https://orcid.org/0000-0002-1039-8732 Universidade Tecnológica Federal do Paraná, Brazil E-mail: leticiasfrancica@gmail.com

Talles Neves de Tofolli

ORCID: https://orcid.org/0000-0002-4370-6105 Universidade Tecnológica Federal do Paraná, Brazil

E-mail: tallesndt@gmail.com

Flávia Vieira da Silva Medeiros

ORCID: https://orcid.org/0000-0001-6490-8876 Universidade Tecnológica Federal do Paraná, Brazil E-mail: flaviav@utfpr.edu.br

Débora Cristina de Souza

ORCID: https://orcid.org/0000-0001-6916-6330 Universidade Tecnológica Federal do Paraná, Brazil E-mail: dcsouza@utfpr.edu.br

Paulo Agenor Alves Bueno

ORCID: https://orcid.org/0000-0002-8929-1400 Universidade Tecnológica Federal do Paraná, Brazil

E-mail: pauloaabueno@gmail.com

Edmilson Antônio Canesin

ORCID: https://orcid.org/0000-0002-5067-4113

Universidade Tecnológica Federal do Paraná, Brazil

E-mail: prof.canesin@utfpr.edu.br

Ana Paula Peron

ORCID: https://orcid.org/0000-0003-2598-2621

Universidade Tecnológica Federal do Paraná, Brazil

E-mail: anaperon@utfpr.edu.br

\begin{abstract}
The Catingueiro, Cristalino and Ligeiro Rivers, present in the eastern region of Cianorte, Paraná, Brazil, are under constant influence of industrial effluents and agrochemicals. In 2022, the public supply of this municipality will be made by waters of the Ligeiro River, and the sites predicted for abstraction are close to the sites of confluence of the Catingueiro River and the Cristalino River with the Ligeiro River. We evaluated in two periods of 2020, based on different parameters, the water quality of the Catingueiro River at two sites, P1 and P2 (P2, upstream of the confluence), the Cristalino River in one site, P3, and the Ligeiro River at two sites, P4 and P5 (P5, downstream of the confluence). Levels of nitrite, nitrate and sulfate in waters were within the range set by law. All points had a high concentration of fluorides and phosphato in the two collections. In P1, in both collections, a high concentration of copper was found. P1 and P2, in the second collection, presented high levels of aluminum. Silicon was detected at all sites. Waters were phytotoxic to L. sativa and cytotoxic to the root meristems of A. cepa. Physical-chemical and toxicity analyses suggest a compromise in water quality. These data are an alert to the public authorities of Cianorte and Paraná regarding the anthropic actions carried out in these rivers and alert the sanitation company to carry out a preliminary and periodic analysis of the waters in order to know the contaminants present before treating them.
\end{abstract}

Keywords: Springs; Physical-chemical parameters; Cytotoxicity; Genotoxicity; Phytotoxicity; Anthropic actions. 


\begin{abstract}
Resumo
Os rios Catingueiro, Cristalino e Ligeiro, presentes na região leste de Cianorte, Paraná, Brasil, estão sob constante influência de efluentes industriais e agroquímicos. Em 2022, o abastecimento público deste município será feito pelas águas do rio Ligeiro, e os locais previstos para captação são próximos aos locais de confluência do rio Catingueiro e do rio Cristalino com o Ligeiro. Avaliou-se em dois períodos de 2020, com base em parâmetros diferentes, a qualidade da água do Rio Catingueiro em dois locais, P1 e P2 (P2, a montante da confluência), o Rio Cristalino em um local, P3, e o Rio Ligeiro em dois locais, P4 e P5 (P5, a jusante da confluência). Os níveis de nitrito, nitrato e sulfato nas águas estiveram dentro da faixa definida por lei. Todos os pontos apresentaram alta concentração de flúor e fosfato nas duas coletas. Em P1, em ambas as coletas, foi encontrada alta concentração de cobre. P1 e P2, na segunda coleta, apresentaram altos teores de alumínio. O silício foi detectado em todos os pontos. As águas foram fitotóxicas para L. sativa e citotóxicas para os meristemas das raízes de A. cepa. Análises físico-químicas e de toxicidade sugerem um comprometimento na qualidade da água. Esses dados alertam os poderes públicos de Cianorte e do Paraná sobre as ações antrópicas realizadas nesses rios e alertam a empresa de saneamento para fazer uma análise preliminar e periódica das águas para conhecer os contaminantes presentes antes de tratá-los.
\end{abstract}

Palavras-chave: Mananciais; Citotoxicidade; Genotoxicidade; Fitotoxicidade ações antrópicas.

\title{
Resumen
}

Los ríos Catingueiro, Cristalino y Ligeiro, presentes en la región oriental de Cianorte, Paraná, Brasil, están constantemente bajo la influencia de efluentes industriales y agroquímicos. En 2022, el abastecimiento público de este municipio se hará por las aguas del río Ligeiro, y los lugares previstos para la recolección están próximos a los lugares donde confluyen el río Catingueiro y el río Cristalino con el río Ligeiro. Se evaluó en dos periodos de 2020, con base en diferentes parámetros, la calidad del agua del río Catingueiro en dos localidades, P1 y P2 (P2, aguas arriba de la confluencia), el río Cristalino en una localización, P3 y el río Ligero. en dos ubicaciones, P4 y P5 (P5, aguas abajo de la confluencia). Los niveles de nitrito, nitrato y sulfato en el agua estaban dentro del rango definido por la ley. Todos los puntos mostraron altas concentraciones de flúor y fosfato en ambas colecciones. En P1, en ambas colecciones, se encontró una alta concentración de cobre. P1 y P2, en la segunda colección, mostraron altos contenidos de aluminio. Se detectó silicio en todos los puntos. Las aguas fueron fitotóxicas para L. sativa y citotóxicas para los meristemas de las raíces de A. cepa. Los análisis físicoquímicos y de toxicidad sugieren un compromiso en la calidad del agua. Estos datos alertan a las autoridades públicas de Cianorte y Paraná sobre las acciones antrópicas que se llevan a cabo en estos ríos y alertan a la empresa sanitaria para que realice un análisis preliminar y periódico de las aguas para conocer los contaminantes presentes antes de tratarlos.

Palabras clave: Manantiales; Citotoxicidad; Genotoxicidad; Fitotoxicidad; Acciones antropogênicas.

\section{Introduction}

Punctual and diffuse sources of pollution can cause physical, chemical and/or biological changes in a water body, impeding its use. Worldwide, the destruction of flooded areas, the suppression of riparian forests, pollution and contamination of rivers by the discharge of urban and agricultural effluents, have caused loss of water quality and availability, resulting in environmental, social and economic consequences (Chan-Keb et al., 2018; Mendes et al., 2021).

The municipality of Cianorte is located in the northwest of the state of Paraná, Brazil, with a territorial area of 809.23 $\mathrm{km}^{2}$ and a population of 82,620 inhabitants, according to the Brazilian Institute of Geography and Statistics (IBGE, 2019). It is a large textile center where six large industrial laundries for dyeing and washing denim are located, one of them is the largest industrial laundry in Latin America (Santos \& Carmo, 2020). Effluents generated after treatments by these companies are discharged in storm sewers of the city with subsequent transport to the Catingueiro and Cristalino Rivers, which are tributaries of the Ligeiro Rivers (Gonçalves, 2020). The Ligeiro River flows into the Ivaí River, one of the great tributaries of the Paraná River, and is part of the Paraná River Basin. In the outskirts of this city, on the banks of the Catingueiro, Cristalino and Ligeiro Rivers there is a large agricultural area, considered a major producer of soybeans and corn in Brazil and in the world, which consequently is under high spraying of pesticides and fertilizer applications throughout the year (Souza et al., 2019).

Currently, in Cianorte, water is abstracted for public supply from the Bolívar River, located to the west of this municipality. However, with the broad urban development taking place in its direction and with a negative impact on its waters, in mid-2021, according to the Paraná Sanitation Company (SANEPAR), the waters of the Ligeiro River will be used 
for public supply of this municipality (Silva, 2020; Sanepar, 2021). Thus, it is relevant to assess, under different aspects, the water quality of the Catingueiro, Cristalino and Ligeiro Rivers in order to ensure the welfare of different species.

In Brazil, CONAMA (National Environment Council) Resolution 357/2005, based mainly on physical and chemical parameters, classifies water bodies into different classes of use. Such parameters allow the knowledge of the factors determining the origin and the nature of residues in water bodies (Brasil, 2005; Barbério et al., 2009; Mendes et al., 2020). However, according to Mendes et al. (2021), in that country the toxicological potential of contaminants in rivers remains little explored in the assessment of environmental risk.

Thus, toxicity assessments in different bioassays, combined with the results of physical and chemical analyses, should be considered in determining the quality of water from natural resources under constant human pressure (Brack et al., 2017). Studies like these provide subsidies that reinforce to the public power the need to inspect the human activities carried out in the surroundings and/or in the water resources, and in the implementation of management plans for the restoration/preservation of these places (Chan-Keb et al., 2018; Mendes et al., 2020).

Vascular plants are recommended by the US Environmental Protection Agency as test organisms for assessing and monitoring contaminants in different environmental matrices (Herrero et al., 2012). Among the internationally accepted tests for assessing environmental quality are the bioassays on Lactuca sativa L. (lettuce), where its seeds and seedlings are routinely used to determine the toxic effects of compounds in terrestrial environments and water bodies, as they are sensitive even to low concentrations (Zhao et al., 2016; Paredes et al. 2016; Mendes et al., 2021). This species presents fast germination and linear root growth in a wide range of $\mathrm{pH}$ (Mtisi \& Willis 2019; Priac et al., 2017; Souza et al., 2020). It is also considered more sensitive in assessing the toxicity of pollutants than other plant test systems (Silveira et al., 2017; Chan-Keb et al., 2018; Mendes et al., 2021). With the results of germination and root elongation obtained through this bioassay, it is possible to predict the cytotoxic potential of substances, mixtures of compounds and waters.

The meristematic cells of Allium cepa $\mathrm{L}$. roots are routinely used to determine the toxic effects of compounds present in terrestrial environments and water bodies (Malakahmad et al., 2018; Sacramento et al., 2020). Biomarkers used in this assay are the mitotic index (cell division index), to evaluate the different levels of cytotoxicity, and the frequency of chromosomal and mitotic spindle changes, for genotoxicity evaluation (Yuet Ping et al., 2012; Matos et al., 2017; Silva et al., 2020). The results obtained by means of the Allium cepa bioassay have a good correlation with the results observed in genetic tests carried out in other bioassays, such as those with animals and cell culture (Palacio et al., 2005; Barbério et al., 2009; Tabrez et al., 2011; Herrero et al., 2012; Sales et al., 2017; Mendes et al., 2020).

Based on the above, the aim of this study was to evaluate chemical parameters, the phytotoxic potential in $L$. sativa and the cytotoxic and genotoxic potentials in meristematic cells of A. cepa roots, from waters located at strategic sites in the Catingueiro, Cristalino and Ligeiro Rivers near the municipality of Cianorte.

\section{Methodology}

The present study characterizes a qualitative research, according to Koche (2011).

\subsection{Study area, sampling periods and sites}

The municipality of Cianorte is located in the central-western geographical mesoregion of the State of Paraná, southern Brazil, at $23^{\circ} 40^{\prime} 00^{\prime}$ "south latitude and $52^{\circ} 38^{\prime} 00^{\prime \prime}$ west longitude of the Greenwich meridian, at an average altitude of 630 meters above sea level, and $510 \mathrm{~km}$ from Curitiba, the state capital.

The Catingueiro, Cristalino and Ligeiro rivers, located in the eastern part of the municipality, are classified as Class II rivers (which characterize waters that require treatment for human consumption) by CONAMA Resolution 357/2005 (Brasil, 
2005). The prevailing climate in the Cianorte region is humid subtropical and the average annual rainfall is $1,500 \mathrm{~mm}$ (Cianorte, 2021).

Five water sampling sites were set (Figure 1). Two of them were set in Catingueiro River (P1 e P2), one in Cristalino River (P3) and two in Ligeiro River (P4 e P5). The points P4 and P5 located on the river Ligeiro, close to the confluence with the rivers Catingueiro and Cristalino, respectively, are very close to the places expected to collect water for public supply in the city of Cianorte.

Figure 1. Geographic location of five water sampling sites (P) in rivers located east of Cianorte, state of Paraná, Brazil. Catingueiro River (P1 and P2), Cristalino River (P3), Ligeiro River (P4 and P5).

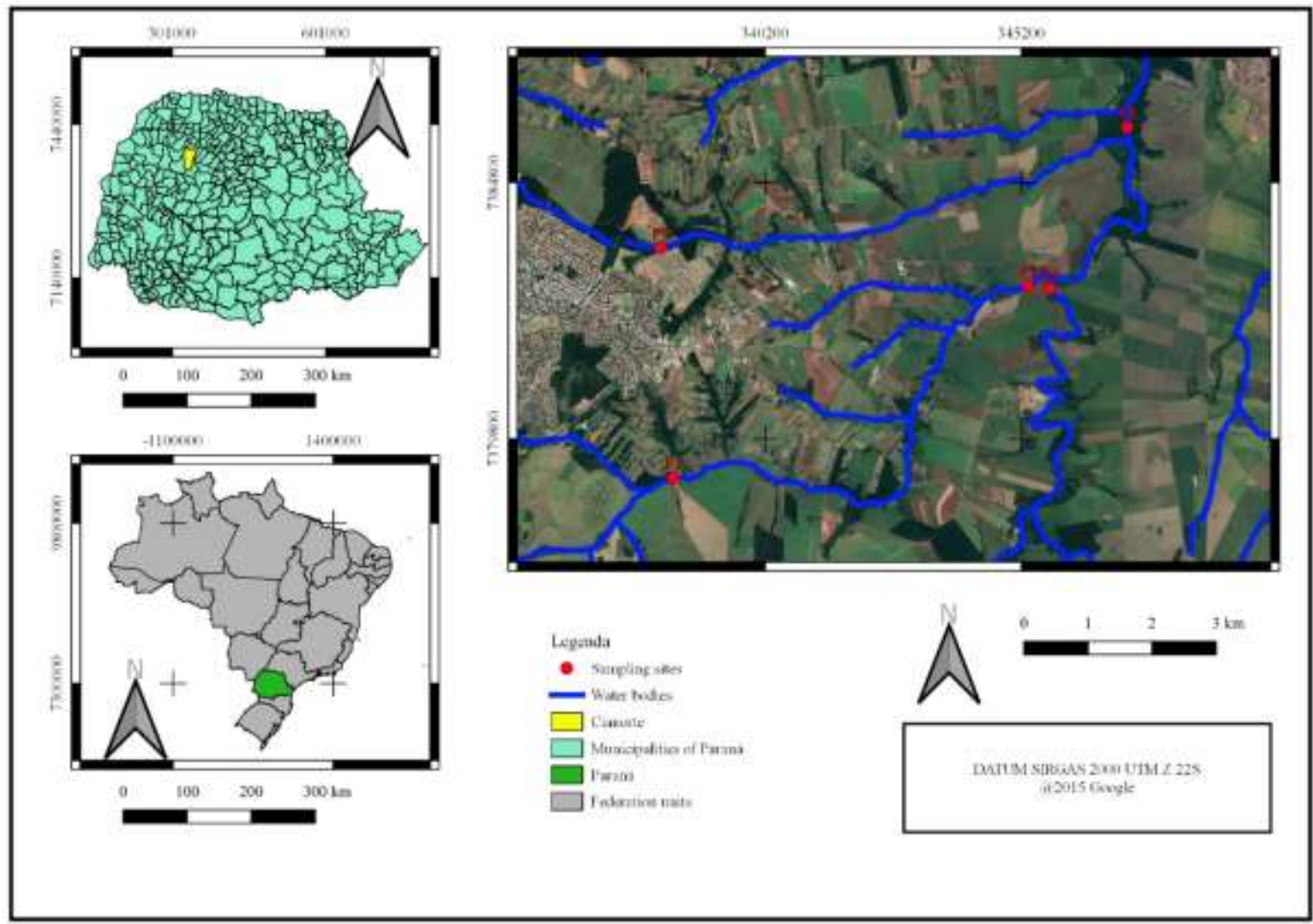

Source: Authors.

The river to which each site belongs, the geographic coordinates and the characterization of the surroundings of each site are described in Table 1. 
Table 1. Identification, river to which it belongs, geographical coordinates and characterization of the banks of five water sampling sites distributed in the eastern area of Cianorte, state of Paraná, Brazil.

\begin{tabular}{|c|c|c|c|c|}
\hline ites & River & $\begin{array}{r}\text { Geog } \\
\text { coordinates }\end{array}$ & & Characterization of water sampling sites \\
\hline 1 & $\begin{array}{l}\text { Catingueir } \\
\text { o River }\end{array}$ & $\begin{array}{c}\text { N. } \\
\text { E. } 7379022\end{array}$ & 338400 & $\begin{array}{l}\text { Located in an urban area, however, close to agricultural } \\
\text { areas. Deposit of a large amount of sand on one of the banks. } \\
\text { Suppression of riparian forest on both banks. High water flow. } \\
\text { Soybean and corn crops very close to the banks of the river. }\end{array}$ \\
\hline 2 & $\begin{array}{l}\text { Catingueir } \\
\text { o River }\end{array}$ & $\begin{array}{c}\text { N. } \\
\text { E. } 7382780\end{array}$ & 345338 & $\begin{array}{l}\text { Located in a rural area. A seemingly intact riparian forest } \\
\text { on both banks. Soybean and corn crops close to both banks. } \\
\text { High water flow. }\end{array}$ \\
\hline 3 & $\begin{array}{l}\text { Cristalino } \\
\text { River }\end{array}$ & $\begin{array}{c}\text { N. } \\
\text { E. } 7383519\end{array}$ & 338152 & $\begin{array}{l}\text { Located in an urban area. Presence at the site of a pipe } \\
\text { belonging to a storm sewer. Riparian forest apparently } \\
\text { preserved on both banks. High water flow. }\end{array}$ \\
\hline 4 & Ligeiro & $\begin{array}{c}\text { N. } \\
\text { E. } 7382713\end{array}$ & 345729 & $\begin{array}{l}\text { Located in a rural area. Soybean crops near the banks of the } \\
\text { river. Gully banks. Upstream of the confluence with the } \\
\text { Catingueiro River. Region destined for the abstraction of water } \\
\text { for public supply in Cianorte. High water flow. }\end{array}$ \\
\hline 5 & Ligeiro & $\begin{array}{c}\mathrm{N} . \\
\text { E. } 7385883\end{array}$ & 347267 & $\begin{array}{l}\text { Located in a rural area. Soybean crops on both banks of } \\
\text { the river. Gully banks. Very high water flow. Downstream of } \\
\text { the confluence with the Cristalino River. Region destined for } \\
\text { the abstraction of water for public supply in Cianorte. High } \\
\text { water flow. }\end{array}$ \\
\hline
\end{tabular}

P: Water sampling site. N: North, E: East. Source: Authors.

Water collections were carried out in two periods of the year 2020, one in February (rainy) and another in October (dry). The indicators considered as water quality parameters in this study were physical-chemical parameters - pH, Conductivity, Fluorides, Chlorides, Nitrite, Nitrate, Phosphate, Sulfate, Total Dissolved Solid, Iron, Aluminum, Copper, Zinc, Manganese, Lead, Chromium, Calcium, Sodium, Potassium and Silicon - the phytotoxic potential in L. sativa and the cytotoxic and genotoxic potential in A. cepa.

\subsection{Collection, storage and disposal of water samples}

Water samples were collected in the morning, $20 \mathrm{~cm}$ deep, $10 \mathrm{~m}$ from the margins, in sterile and sealed polyethylene bottles with a capacity of $1 \mathrm{~L}$. For each location, two bottles were removed. Then, the water samples were transported refrigerated to the Federal Technological University of Paraná in Campo Mourão, from where part of the flasks were sent for toxicity assessment at the Ecology Laboratory. Part of the water samples was sent, on the same day of collection (refrigerated) to the Federal Technological University, in Apucarana, for physical and chemical analyzes.

\subsection{Physical and chemical analysis}

The results of physical and chemical analyses were evaluated based on the parameters CONAMA Resolution 357/2005 (Brasil, 2005).

The conductivity of the water samples was evaluated by a bench conductivity meter. Fluoride concentrations determined by specific fluorimeter with SPADNS reagent and chlorides were obtained by volumetric titration. The concentrations of nitrite, nitrate and phosphate were evaluated by UV-Vis spectrophotometry, and sulfate by turbidimetry. 
Total solids were determined by gravimetry. The metals $\mathrm{Fe}, \mathrm{Al}, \mathrm{Cu}, \mathrm{Zn}, \mathrm{Mg}, \mathrm{Pb}$ and $\mathrm{Cr}$ were analyzed by flame atomic spectrophotometry.

The analyzes are in accordance with the methods described in Standard Methods for Examination of water and Wastewater (Eaton et al., 2005).

\subsection{Analysis of Germination potential and Relative Growth Index of Lactuca sativa radicles}

The seeds of L. sativa (Isla $\left.{ }^{\circledR}\right)$ were obtained from an agricultural products store and did not contain any type of pesticide. According to information on the packages, the germination rate of the batch was $98 \%$, and the experiment used seeds from the same batch. The tests were carried out in $100 \times 15 \mathrm{~mm}$ glass Petri dishes, previously sterilized in an autoclave. Two sheets of Whatman ${ }^{\circledR}$ \# 3 filter paper were placed on each plate to support the seeds.

The waters in L. sativa were evaluated for the parameters Germination Rate, Radicle Elongation and Relative Growth Index of the Roots. For each parameter, in each location, undamaged seeds of similar sizes were separated with the aid of a stereoscopic magnifying glass and placed on filter paper in Petri dishes (thirty seeds per plate). The sampled waters considering each parameter evaluated and their respective controls with distilled water - were analyzed in quintuplicate.

For the Germination Rate evaluation, $5 \mathrm{~mL}$ of sample water was poured into Petri dishes and then covered. The plates were incubated in a BOD germination chamber with a 12-hour photoperiod, at $24 \pm 1{ }^{\circ} \mathrm{C}$, for 24 hours. Then, the number of germinated seeds for each location was counted and the Germination Rate was calculated as follows: GR = (Number of seeds germinated from the treatment) / (Number of seeds germinated in the negative control) x 100 .

Likewise, to calculate the Radicle Elongation and Relative Growth Index of the Roots, $5 \mathrm{~mL}$ of sample water was poured into Petri dishes, which were then covered. Then, they were incubated in a BOD germination chamber, with a 12-hour photoperiod, at $24 \pm 1{ }^{\circ} \mathrm{C}$, for 168 hours (seven days). After seven days of incubation, ten germinated seeds were collected randomly from each plate, from each location under analysis, and the length of the roots was measured with a caliper. For each treatment, the root lengths were calculated and divided by five, obtaining the value of Radicle Elongation. Then, Relative Growth Index of the Roots was calculated using the following formula: (Average root length in each treatment) / (Average root length of the control). RGI values were classified into three categories, according to Biruk et al. (2012): root growth inhibition (I): $0<\mathrm{x}<0.8$; without significant treatment effect (SES): $0.8 \leq x \leq 1.2$; and significant treatment effect (E): $x \geq 1.2$.

For the analysis of the germination and root elongation data obtained, the one-way ANOVA and the Dunnet post hoc test with a significance of 0.05 were used.

\subsection{Water cytotoxicity and genotoxicity analysis in Allium cepa root meristems}

For the assessment of cytotoxicity and genotoxicity of water, onion bulbs (variety beta cristal, from an organic garden) were placed in vials with distilled water, constantly aerated, to obtain roots of $2.0 \mathrm{~cm}$ in length. For the analysis of each colletion point and controls, an experimental group of five onion bulbs was set up. After rooting the bulbs in distilled water, roots were placed in contact with the sampled water where they remained for 24 hours.

A negative control, with only distilled water, was prepared. A positive control was prepared with methyl methanesulfonate (MMS), a substance known to be cytotoxic and genotoxic to the A. cepa test system, at the concentration $4 \times 10^{-4}$ mol.L $\mathrm{L}^{-1}$. All roots collected during the experiment were fixed in 3: 1 Carnoy solution (ethanol: acetic acid) for up to 24 hours, according to Guerra and Souza (2002) protocol. For estimates of the mitotic index, cells in interphase, prophase, metaphase, anaphase and telophase were counted to determine the cytotoxic potential. The mitotic index or cell division index was calculated as follows: (Total number of dividing cells/Total number of cells analyzed) x 100. Genotoxic potential was 
assessed by frequency of cell alterations such as micronuclei, colchicine metaphases, anaphase and telophase bridges, gene amplifications, cells with adhesions, nuclear buds and multipolar anaphases.

The results in A. сера were tested by analysis of variance (ANOVA) and the mean values were compared by the Scott-Knott test at a significance of 0.05 .

\section{Results and Discussion}

Waters from the five sampling sites, in the two periods of 2020, showed $\mathrm{pH}$ and levels of nitrite, nitrate and sulfate (Table 2) within the range set by CONAMA Resolution 357/2005. These results suggest that water is not polluted by domestic effluents. However, the presence of a high concentration of fluorides and phosphate in the water in the two collections, suggest water pollution by agrochemicals, pesticides and leachate fertilizers (Guimarães et al., 2014; Aguiar et al., 2018; Lim et al., 2018). The presence of fluorides, chlorides (even in line with the law considered) and phosphate in the waters is also a result of urban waste transported by the city's rain galleries, as those from domestic and industrial cleaning agent (Damasceno et al., 2015). According to Barbério et al. (2009) and Mendes et al. (2021), the presence of these three compounds in natural waters even at permitted concentrations, when combined with other conditions, such as the presence of salts and/or metals in water, form complex structures that can cause significant adverse effects, such as toxicity to organisms and death. 
Table 2. Physical-chemical analyzes carried out in February and October on water samples of Catingueiro (P1 and P2), Cristalino (P3) and Ligeiro (P4 and P5) rivers in Cianorte, Paraná, Brazil.

\begin{tabular}{|c|c|c|c|c|c|c|}
\hline \multicolumn{7}{|c|}{ Collection carried out in February 2020} \\
\hline Parameter & CONAMA 357/2005 & P1 & P2 & P3 & P4 & P5 \\
\hline $\mathrm{pH}$ & 6 to 9 & 7.3 & 7.5 & 7.1 & 7.2 & 6.9 \\
\hline Fluorides $\left(\mathrm{mg} \cdot \mathrm{L}^{-1}\right)$ & MAV 1.4 & 3.7 & 2.2 & 2.1 & 2.1 & 2.0 \\
\hline Chlorides $\left(\mathrm{mg} \cdot \mathrm{L}^{-1}\right)$ & MAV 250.0 & 16.4 & 18.8 & 19.5 & 18.8 & 24.8 \\
\hline Nitrite $\left(\mathrm{mg} \mathrm{L}^{-1}\right)$ & MAV 1.0 & 0.02 & nd & nd & nd & nd \\
\hline Nitrate $\left(\mathrm{mg} \mathrm{L}^{-1}\right)$ & MAV10.0 & 8.6 & 8.3 & 4.3 & 2.4 & 3.2 \\
\hline Phosphate (mg L-1) & MAV 0.025 & 0.040 & 0.035 & 0.030 & 0.045 & 0.050 \\
\hline Sulfate $\left(\mathrm{mg} \mathrm{L}^{-1}\right)$ & MAV 250.0 & 38.5 & 24.2 & 14.1 & 13.2 & 9.7 \\
\hline Total Dissolved Solids $\left(\mathrm{mg} \cdot \mathrm{L}^{-1}\right)$ & MAV 500.0 & 125.0 & 118.0 & 96.2 & 47.3 & 38.2 \\
\hline $\operatorname{Iron}\left(\mathrm{mg} \mathrm{L}^{-1}\right)$ & MAV 0.3 & 0.1 & 0.1 & 0.1 & 0.1 & 0.1 \\
\hline Aluminum $\left(\mathrm{mg} \cdot \mathrm{L}^{-1}\right)$ & MAV 0.1 & nd & nd & nd & nd & nd \\
\hline Copper $\left(\mathrm{mg} \cdot \mathrm{L}^{-1)}\right.$ & MAV 0.009 & 0.100 & nd & nd & nd & nd \\
\hline Zinc $\left(\mathrm{mg} \mathrm{L}^{-1}\right)$ & MAV 0.18 & nd & nd & nd & nd & nd \\
\hline Manganese $\left(\mathrm{mg} \mathrm{L}^{-1}\right)$ & MAV 0.10 & 0.10 & nd & nd & 0.03 & nd \\
\hline Lead $\left(\mathrm{mg} \mathrm{L}^{-1}\right)$ & MAV 0.01 & nd & nd & nd & nd & nd \\
\hline Chromium $\left(\mathrm{mg} \cdot \mathrm{L}^{-1}\right)$ & MAV 0.05 & nd & nd & nd & nd & nd \\
\hline & $\begin{array}{l}\text { ements not considered } \\
\text { CONAMA 357/2005 }\end{array}$ & & & & & \\
\hline
\end{tabular}




\begin{tabular}{|c|c|c|c|c|c|c|}
\hline Conductivity $\left(\mu \mathrm{S} \cdot \mathrm{cm}^{-1}\right)$ & & 145.4 & 116.4 & 181.8 & 133.8 & 139.5 \\
\hline Calcium & & 3.1 & 3.3 & 4.2 & 3.5 & 3.2 \\
\hline Sodium $\left(\mathrm{mg} \cdot \mathrm{L}^{-1}\right)$ & & 43.3 & 31.2 & 37.4 & 36.4 & 34.6 \\
\hline Potassium (mg L-1) & & 3.7 & 4.2 & 4.3 & 0.9 & 1.4 \\
\hline Silicon $\left(\mathrm{mg} \cdot \mathrm{L}^{-1}\right)$ & & 17.9 & 17.4 & 15.4 & 17.2 & 14.9 \\
\hline \multicolumn{7}{|c|}{ Collection carried out in October 2020} \\
\hline Parameter & CONAMA 357/2005 & $\mathrm{P} 1$ & P2 & P3 & P4 & P5 \\
\hline $\mathrm{pH}$ & 6 to 9 & 6.7 & 7.2 & 7.0 & 7.1 & 7.1 \\
\hline Fluorides $\left(\mathrm{mg} \cdot \mathrm{L}^{-1}\right)$ & MAV 1.4 & 1.9 & 2.5 & 2.2 & 2.3 & 2.3 \\
\hline Chlorides $\left(\mathrm{mg} \cdot \mathrm{L}^{-1}\right)$ & MAV 250.0 & 34.9 & 22.1 & 44.4 & 39.1 & 51.4 \\
\hline Nitrite $\left(\mathrm{mg} \mathrm{L}^{-1}\right)$ & MAV 1.0 & nd & 0.10 & nd & nd & nd \\
\hline Nitrate $\left(\mathrm{mg} \mathrm{L}^{-1}\right)$ & MAV10.0 & 9.8 & 9.5 & 8.50 & 1.85 & 4.10 \\
\hline Phosphate (mg L-1) & MAV 0.025 & 0.080 & 0.045 & 0.085 & 0.095 & 0.095 \\
\hline Sulfate $\left(\mathrm{mg} \mathrm{L}^{-1}\right)$ & MAV 250.0 & 42.8 & 30.4 & 12.2 & 10.6 & 6.5 \\
\hline Total dissolved solids $\left(\mathrm{mg} \cdot \mathrm{L}^{-1}\right)$ & MAV 500.0 & 196.0 & 124.0 & 108.0 & 78.4 & 56.5 \\
\hline $\operatorname{Iron}\left(\mathrm{mg} \mathrm{L}^{-1}\right)$ & MAV 0.30 & 0.10 & 0.03 & nd & nd & nd \\
\hline Aluminum $\left(m g \cdot \mathrm{L}^{-1}\right)$ & MAV 0.1 & 4.3 & 5.6 & nd & nd & nd \\
\hline Copper $\left(\mathrm{mg} \cdot \mathrm{L}^{-1}\right)$ & MAV 0.009 & 0.100 & nd & nd & nd & nd \\
\hline $\operatorname{Zinc}\left(\mathrm{mg} \mathrm{L}^{-1}\right)$ & MAV 0.18 & nd & nd & nd & 0.03 & nd \\
\hline Manganese (mg L-1) & MAV 0.10 & nd & nd & 0.04 & nd & nd \\
\hline
\end{tabular}


Research, Society and Development, v. 10, n. 8, e27610817336, 2021

(CC BY 4.0) | ISSN 2525-3409 | DOI: http://dx.doi.org/10.33448/rsd-v10i8.17336

\begin{tabular}{|c|c|c|c|c|c|c|}
\hline Lead $\left(\mathrm{mg} \mathrm{L}^{-1}\right)$ & MAV 0.01 & nd & nd & nd & nd & nd \\
\hline \multirow[t]{2}{*}{ Chromium $\left(\mathrm{mg} \cdot \mathrm{L}^{-1}\right)$} & MAV 0.05 & nd & nd & nd & nd & nd \\
\hline & $\begin{array}{l}\text { Elements not considered by } \\
\text { CONAMA 357/2005 }\end{array}$ & & & & & \\
\hline Conductivity $\left(\mu \mathrm{S} \cdot \mathrm{cm}^{-1}\right)$ & & 188.3 & 186.1 & 113.7 & 135.95 & 158.62 \\
\hline Calcium & & 2.8 & 4.2 & 5.1 & 6.6 & 2.0 \\
\hline Sodium & & 61.1 & 68.7 & 40.2 & 64.2 & 68.7 \\
\hline Potassium & & 4.89 & 4.13 & 2.29 & 1.06 & 1.53 \\
\hline Silicon & & 16.4 & 18.2 & 10.3 & 6.2 & 5.2 \\
\hline
\end{tabular}

P: collect point, DO: dissolved oxygen, pH: potential of hydrogen, MAV: Maximum Allowable Value, nd: not detected. CONAMA: National Environment Council. Source: Authors. 
Table 2 lists the results of the physical-chemical analyzes of the waters of the three rivers. Through these results it will be possible to infer about the results of the toxicity analyses.

Conductivity was considered for the evaluation of the five sampling sites. This parameter expresses the water's capacity to conduct an electric current and characterizes the presence of salts (Vasconcelos et al., 2011; Andrade et al., 2012). According to Table 2, the presence of calcium, sodium and potassium was found in the water samples of the five points, in the two analyzes performed, a condition that corroborates the conductivity results for the five points, with higher values for the first three points.

Analyses of the metals iron, manganese, lead and chromium in the waters from the five sampling sites in the two periods, considering the CONAMA Resolution 357/2005, were within the acceptable range or were not detected. Copper was an exception at site 1 in both collections, and aluminum was above the limit at sites 1 and 2 in October. The copper concentration allowed by the Brazilian resolution in springs and in springs tributaries is $0.009 \mathrm{mg} \mathrm{L}^{-1}$, and the data obtained for the waters of P1 in February and October 2020 were $0.100\left(\mathrm{mg} \mathrm{L}^{-1}\right)$. Aluminum was the most worrying, as the maximum aluminum concentration allowed for class II rivers in Brazil is $0.1 \mathrm{mg} \mathrm{L}^{-1}$, and the values found for P1 and P2, in October were 4.35 and $5.65 \mathrm{mg} \mathrm{L}^{-1}$, respectively.

Copper is found in the chemical composition of a variety of pesticides, such as those indicated for soybean and corn crops (Dong et al., 2020). As reported in Table 1, the banks of site 1 have reduced riparian forest and the presence of soybe an crops very close to both banks of the river, in addition to the removal of native forest to deposit a large amount of sand on one of the banks, conditions that increase the loading of contaminated soil into the Catingueiro River during periods of rain and, consequently, the contamination of its waters by this metal.

For sites 1 and 2, in the second sampling conducted, there was a high concentration of aluminum in waters. According to Table 1, considering the sampling in October, there were corn crops very close to this site. Sites 1 and 2 belong to the same river, Catingueiro. The presence of a high concentration of this element in the water results from soil leaching and/or by pesticide drift by wind during application in the crop (Paraginski et al., 2015; Aguiar et al., 2019). Furthermore, according to Figure 1, between sites 1 and 2 there are three tributaries that also transport residues from the agricultural and urban areas to the Catingueiro River.

It is important to emphasize that sites 1 and 2 have a high flow of water, which allows the transportation of these metals to other locations, such as the Ligeiro River. Besides that, denim dyeing industries, such as those of Cianorte, use coagulating agents, such as aluminum sulfate, to form flakes that are separated by filtration or sedimentation during effluent treatment. This condition reduces dissolved, suspended solids, colloids and organic matter, as well as the color of textile effluents, allowing the reuse of much of the water (Porto \& Schoenhals, 2013). However, part of the used coagulant is discarded with the treated effluent in the city's storm sewer system and carried to nearby rivers, such as Catingueiro. According to Porto and Schoenhals (2013), there are denim laundries in Cianorte that use, on average, $600 \mathrm{Kg}$ aluminum sulfate per day in the treatment of their effluents.

Silicon was detected in all sites in both samplings. This compound is commonly found in fertilizers, such as those used in soybean and corn crops (Buck et al., 2010). The presence of high levels of copper and aluminum, as well as the constant presence of silicon, in natural waters can dramatically affect the flow of the food chain as it presents cumulative potential and cause the death of different species (Vlček et al., 2018; Li et al., 2020). In addition, conventional water treatments, such as those used by water treatment plants in Brazil, do not have the capacity to remove these metals from water intended for consumption (Guimarães et al., 2013).

Based on the results of phytotoxicity in Figure 2, for all sites, there was inhibition of the germination of L. sativa seeds moistened with waters from the Catingueiro, Cristalino and Ligeiro Rivers, after 24 hours of exposure, in the two 
collections conducted, when compared to germination percentage for the control in the two periods considered. Still, considering the results in Figure 2, there was an inhibition in the elongation and relative growth of the roots exposed to waters of the five sites analyzed in the two samplings.

Figure 3. Germination seed (A and B), Radicle Alongation (C and D) and Relative Growth Index (E and F) in roots of Lactuca sativa subjected to waters from the Catingueiro (P1 and P2), Cristalino (P3) and Ligeiro rivers (P4 and P5).
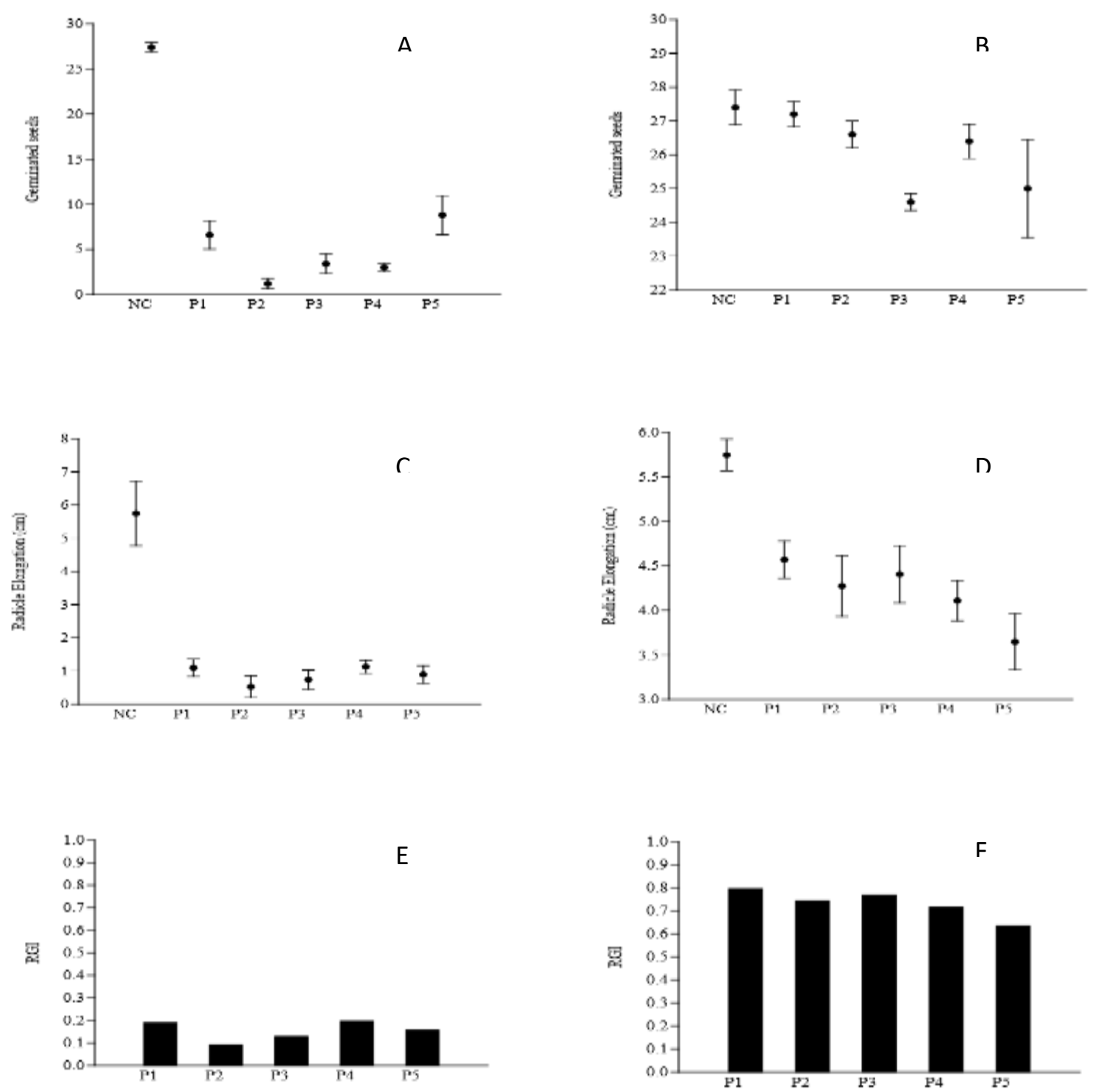

NC - Negative control, P - Sampling site, RGI - Relative Growth Index. Letters A, C and E refer to the collection carried out in February. Letters B, D and F refer to collections made in October. For the analysis of the germination and root elongation data the one-way ANOVA and the Dunnet post hoc test with a significance of 0.05 were used. Source: Authors.

Through Figure 3 it is possible to observe the action of the waters of the three rivers against the germination of seeds and elongation of roots of $\mathrm{L}$. sativa. 
The reduction in germination rate can occur due to insufficient water entry into the seeds during the imbibition phase, a primordial condition for embryo development. In addition to germination, this condition also affects other physiological processes in the plant, such as elongation and the increase in root biomass (Rodrigues et al., 2013). In the present study, the availability of water for seeds was limited by the mixture of compounds present in waters from the five sites (Table 2). This mixture also impairs cell division of different organs and tissues in the plant (Barbério et al., 2009; Mendes et al., 2020). It is important to report that the roots of $L$. sativa from seeds exposed to waters from the five sites, referring to the two collections, were very thin, and their meristematic regions were practically not visible. Such condition did not allow the evaluation of cytotoxicity and genotoxicity in root meristems in this species.

Based on the results obtained in Table 3, waters from the five sites, in 24 hours of exposure, caused significant inhibition to cell division in the meristems of A. cepa when compared to the value of mitotic index obtained for the negative control. Still, waters of P1 (in February and October), P4 and P5 (in February) showed cell division indices equal to that observed for the positive control, characterizing a drastic inhibition of division in the root tissues. Nevertheless, based on the evaluation of cellular damage, the analyzed waters were not genotoxic to the root tissues (Table 4).

Table 3. Mitotic indices (\%) observed in root meristem cells of Allium cepa exposed for 24 hours to waters of Catingueiro (P1 and P2), Cristalino (P3) e Ligeiro (P4 and P5) rivers in two periods of the year 2020.

\begin{tabular}{ccc}
\hline & Mitotic Index(\%) & \\
\hline Negative Control & & ET 24h \\
\cline { 2 - 3 } & & $40.1 \pm 0.8$ \\
\hline Positive Control & & ET $24 \mathrm{~h}$ \\
\cline { 2 - 3 } & & $7.5 \pm 0.3$ \\
\hline Months & February & October \\
\hline P/ET & $24 \mathrm{~h}^{*}$ & $24 \mathrm{~h}$ \\
\hline P1 & $8.0 \pm 0.10^{*}, \#$ & $14.0 \pm 0.90^{*}, \#$ \\
P3 & $19.3 \pm 0.10^{*}$ & $17.9 \pm 0.80^{*}$ \\
P5 & $15.0 \pm 0.04^{*}$ & $17.5 \pm 0.70^{*}$ \\
\hline
\end{tabular}

ET: exposure times. ET: Exposure Time, MMS: methyl methanesulfonate, P: collect point.

*Values different from the mitotic index obtained for the negative control. \# Values equal to the mitotic index obtained for the positive control. The results were tested by analysis of variance (ANOVA) and the mean values were compared by the Scott-Knott test at a significance of 0.05 .

Source: Authors.

Table 3 shows the action of river waters on the cell division process of root meristems of A. cepa. 
Table 4. Cellular Alterations (\%) observed in A. cepa root meristems exposed to water in the Catingueiro (P1 and P2), Cristalino (P3) and Ligeiro (P4 and P5) rivers in 24 hours exposure.

\section{Cellular Alterations (\%)}

\begin{tabular}{ccc}
\hline Negative Control & \multicolumn{2}{c}{ ET $24 \mathrm{~h}$} \\
\cline { 2 - 3 } & & $0.01 \pm 1.23$ \\
\hline Positive Control & & ET $24 \mathrm{~h}$ \\
\cline { 2 - 3 } & & $8.9 \pm 0.55$ \\
\hline Months & February & October \\
\hline P/ET & $24 \mathrm{~h}$ & $24 \mathrm{~h}$ \\
\hline P1 & $0.01 \pm 0.20^{*}$ & $0.01 \pm 0.10^{*}$ \\
\hline P2 & $0.01 \pm 0.05^{*}$ & $0.02 \pm 0.10^{*}$ \\
P4 & $0.01 \pm 0.10^{*}$ & $0.01 \pm 0.10^{*}$ \\
\hline & $0.02 \pm 0.02^{*}$ & $0.01 \pm 0.10^{*}$ \\
\hline
\end{tabular}

ET:exposure times. ET: Exposure Time, MMS: methyl methanesulfonate, P: collect point. February

* Values different from the mitotic index obtained for the negative control. The results in were tested by analysis of variance (ANOVA) and the mean values were compared by the Scott-Knott test at a significance of 0.05 .

Source: Authors.

Table 4 shows the potential of river waters to cause mitotic spindle changes on meristematic cells and roots of $A$. cepa.

According to Herrero et al. (2012), Guedes et al. (2018), Sales et al. (2017), Silva et al. (2020), Mendes et. al. (2020) mitotic indices significantly lower than the negative control indices, as observed for waters from P1 to P5, in the two samplings (Table 4), indicate the presence of cytotoxic agents with the potential to affect the growth and development of the exposed organisms, such as agrochemicals and heavy metals. These authors declare that the inhibition of cell proliferation triggered by cytotoxic compounds in tissues of intense cell proliferation, however, with normal performance - such as the root meristems used in this study - is quite harmful to organisms because it inhibits or limits cell replenishment, changes protein production and result in organ malfunction. The results of toxicity evidenced in the present study in L. sativa and A. cepa corroborate the physical-chemical data obtained and validate the contamination of the water by urban and agricultural residues.

\section{Final Considerations}

The research reached its main objective, which was to observe the toxic potential of the waters of the three evaluated rivers. 
Our findings suggest the lack of quality of the water for public supply, focusing on waters from P1 and P2, collected in the Cristalino River, due to the presence of heavy metals, and their influence on P4. Still, the analyses performed, considering the three rivers, are pioneering, since in the scientific literature there were no studies on the evaluation of water quality for these water resources. These results are of great relevance in view of demonstrating that the direct and indirect human pressures exerted in these rivers harm them and can cause irreversible damage to different species.

They are also subsidies to the municipal and state public authorities in making decisions regarding the need for inspection and punishment of those responsible for harmful activities in these rivers. The results obtained here also alert the company responsible for water treatment to carry out preliminary and periodic analyzes of the waters of the Rio Ligeiro destined to the public supply of Cianorte, and of tributary rivers with greater influence in its waters to know the contaminants present, before treating them with conventional methods.

\section{References}

Andrade, T. S., Montenegro, S. M., Montenegro, A. A., \& Rodrigues, D. F. (2012). Spatio-temporal variability of groundwater electrical conductivity in the semiarid region of Pernambuco. Revista Brasileira de Engenharia Agrícola e Ambiental, 16, 496-504.

Aguiar, T. R., Neto, J. O. A. G., Şen, U., \& Pereira, H. (2019). Study of two cork species as natural biosorbents for five selected pesticides in water. Heliyon, 5, e01189.

Barbério, A., Barros, L. A. Y. R. A., Voltolini, J. C., \& Mello, M. L. (2009). Evaluation of the cytotoxic and genotoxic potential of water from the River Paraíba do Sul, in Brazil, with the Allium cepa L. test. Brazilian Journal of Biology, 69, 837-842.

Brasil. Conselho Nacional do Meio Ambiente (CONAMA). (2005). Resolution No. 396 of April 3, 2005. Ministério do Meio Ambiente. (in Portuguese).

Biruk, L.N., Moretton, J., Iorio, A.F., Weigandt, C., Etcheverry, J., Filippetto, J., \& Magdaleno, A. (2017). Toxicity and genotoxicity assessment in sediments from the Matanza-Riachuelo river basin (Argentina) under the influence of heavy metals and organic contaminants. Ecotoxicology and Environmental Safety, 135, 302-311. https://doi.org/10.1016/j.ecoenv.2016.09.024

Brack, W., Dulio, V., Ågerstrand, M., Allan, I., Altenburger, R., Brinkmann, M., \& Vrana, B. (2017). Towards the review of the European Union Water Framework Directive: recommendations for more efficient assessment and management of chemical contamination in European surface water resources. Science of the Total Environment, 576, 720-737. https://doi.org/10.1016/j.scitotenv.2016.10.104

Buck, G. B., Korndörfer, G. H., \& Datnoff, L. E. (2010). Extractors for estimating plant available silicon from potential silicon fertilizer sources. Journal of Plant Nutrition, 34, 272-282. https://doi.org/10.1080/01904167.2011.533327

Chan-Keb, C. A., Agraz-Hernández, C. M., Perez-Balan, R. A., Gómez-Solano, M. I., Maldonado-Montiel, T. D., Ake-Canche, B., \& Gutiérrez-Alcántara, E. J. (2018). Acute toxicity of water and aqueous extract of soils from Champotón river in Lactuca sativa L. Toxicology Reports, 5, 593-597. https://doi.org/10.1016/j.toxrep.2018.05.009

Cianorte (2021). Cianorte City Hall. Retriewed January 10, 2021, from https://cianorte.pr.gov.br. (in Portuguese).

Damasceno, M. C. S., Ribeiro, H. M. C., Takiyama, L. R., \& Paula, M. T. (2015). Seasonal assessment of the surface water quality of the Amazon River on the edge of the city of Macapá, Amapá, Brazil. Revista Ambiente \& Água, 10, 598-613.

Dong, W., \& Zhang, Y., \& Quan, X. (2020). Health risk assessment of heavy metals and pesticides: A case study in the main drinking water source in Dalian, China. Chemosphere, 242,125113. https://doi.org/10.1016/j.chemosphere.2019.125113

Eaton, A. D., Clesceri, L. S., \& Greenberg, A. E. (2005). Standard methods for the examination of water and wastewater. Public Health Association. 250p.

Gomes, K. M. S., Oliveira, M. V. G. A. D., Carvalho, F. R. D. S., Menezes, C. C. \& Peron, A. P. (2013). Citotoxicity of food dyes sunset yellow (E-110), bordeaux red (E-123), and tatrazine yellow (E-102) on Allium cepa L. root meristematic cells. Food Science and Technology, 33, 218-223. https://doi.org/10.1590/S0101-20612013005000012

Guedes, C. M., Santos, F. K. S., Silva, T., Silva, A. P. S., Lima, M. V. S., \& Peron, A. P. (2018). Cytotoxic and genotoxic potential of Ginkgo biloba L., in industrialized and without-additive forms. Bioscience Journal, 34, 1017-1024. https://doi.org/10.14393/BJ-v34n1a2018-39745

Guerra, M., \& Souza, M. J. (2002). How to observe chromosomes: a guide to techniques in plant, animal and human cytogenetics. FUNPEC. 270p. 
Gonçalves, E. V. (2020). Water quality of water resources in the city of Cianorte, State of Paraná, Brazil: a city influenced by the presence of jeans laundry and agriculture. Dissertation, Federal Technological University of Paraná. (in Portuguese).

Guimarães, B. S., Kliemann, N., Caldas, S., Costa, F., Silveira, M. A. K., Duarte, F. A., \& Primel, E. S. (2013). Environmentally friendly system for the degradation of multipesticide residues in aqueous media by the Fenton's reaction. Environmental Science and Pollution Research, 21, 584-592. https://doi.org/10.1007/s11356-013-1932-2

Herrero, O., Martín, J. P., Freire, O. F., López, L., Peropadre, A., \& Hazen, M. J. (2012). Toxicological evaluation of three contaminant of emerging concern by use of Allium cepa test. Mutation Research, 743, 24-34.

IBGE (2019). Brazilian Institute of Geography and Statistics. Cities. Retriewed january 10, 2021, from http://cidades.ibge.gov.br/xtras/perfil.php?codmun=410430>. (in Portuguese).

Koche, J. C. (2011). Fundamentos de metodologia científica. Petrópolis: Vozes. http://www.brunovivas.com/wpcontent/uploads/sites/10/2018/07/K\%C3\%B6che-Jos\%C3\%A9-Carlos0D0AFundamentos-de-metodologia-cient\%C3\%ADfica-_-teoriada0D0Aci\%C3\%AAncia-e-inicia\%C3\%A7\%C3\%A3o-\%C3\%A0-pesquisa.pdf 5.2)

Lim, E. S., Lim, M. C., Park, K., Lee, G,. Lim, J. A., Woo, M. A., \& Chang, H. J. (2020). Selective Binding and Elution of Aptamers for Pesticides Based on Sol-Gel-Coated Nanoporous Anodized Aluminum Oxide Membrane. Nanomaterials, 10, 1533. https://doi.org/10.3390/nano10081533

Li, J., Song, Y., Vogt, R. D., Liu, Y., Luo, J., \& Li, T. (2020). Bioavailability and cytotoxicity of Cerium-(IV), Copper-(II), and Zinc oxide nanoparticles to human intestinal and liver cells through food. Science of The Total Environment, 702, 134700. https://doi.org/10.1016/j.scitotenv.2019.134700

Malakahmad, A., Abd Manan, T. S. B., Sivapalan, S., \& Khan, T. (2018). Genotoxicity assessment of raw and treated water samples using Allium cepa assay: evidence from Perak River, Malaysia. Environmental Science and Pollution Research, 25, 5421-5436. https://doi.org/10.1007/s11356-017-0721-8

Matos, L. A., Cunha, A. C., Sousa, A. A., Maranhão, J. P., Santos, N. R., Gonçalves, M. C., \& Ferreira-Junior, H. (2017). The influence of heavy metals on toxicogenetic damage in a Brazilian tropical river. Chemosphere, 185, 852-859. https://doi.org/10.1016/j.chemosphere.2017.07.103

Mendes, S. A., Gonçalves, É. V., Frâncica, L. S., Correia, L. B. C., Nicola, J. V. N., Pestana, A. C. Z., \& Peron, A. P. (2020). Quality of Natural Waters Surrounding Campo Mourão, State of Paraná, Southern Brazil: Water Resources Under the Influences from Urban and Agricultural Activities. Water, Air, \& Soil Pollution, 231, 1-10. https://doi.org/10.1007/s11270-020-04795-5.

Mendes, S. A., Frâncica, L. S., Gonçalves, E. V., Coleto, L. B., Nicola, J. V. N., Pestana, A. C. Z., Souza, D. C., Bueno, P. A. A., Medeiros, F. V. S., Ineu, R. P., Souza, W. E., \& Peron, A. P. (2021). Prospecting for Phytotoxicity and Enzymatic Modulation of Waters from Springs in the Surroundings of Campo Mourão, State of Paraná, Brazil, in Lactuca sativa L. Water, Air, \& Soil Pollution, 232, 42-52. https://doi.org/10.1007/s11270-021-05003-8

Mtisi, M., \& Gwenzi, W. (2019). Evaluation of the phytotoxicity of coal ash on lettuce (Lactuca sativa L.) germination, growth and metal uptake. Ecotoxicology and Environmental Safety, 170, 750-762. https://doi.org/10.1016/j.ecoenv.2018.12.047

Nunes, R. D. M., Sales, I. M. S., Silva, S. I. O., Sousa, J. M. C., \& Peron, A. P. (2017). Antiproliferative and genotoxic effects of nature identical and artificial synthetic food additives of aroma and flavor. Brazilian Journal of Biology, 77, 150-154. http://dx.doi.org/10.1590/1519-6984.12115

Palacio, S. M., Espinoza-Quiñones, F. R., Galante, R. M., Zenatti, D. C., Seolatto, A. A., Lorenz, E. K., Zacarkim, C. E., Rossi, N., Rizzutto, M. A., \& Tabacniks, M. H. (2005). Correlation between heavy metal íons (Copper, Zinc, Lead) concentrations and root length of Allium cepa L. in polluted river water. Brazilian Archives of Biology and Technology, 48, 191-196. http://dx.org/10.1590/S1516-89132005000400024

Paraginski, R. T., Rockenbach, B. A., Santos, R. F., Elias, M. C., \& Oliveira, M. (2015). Quality of corn kernels stored at different temperatures. Revista Brasileira de Engenharia Agrícola e Ambiental, 19, 358-363.

Paredes, P. F. M., Vasconcelos, F. R., Paim, R. T. T., Marques, M. M. M., Morais, S. M., \& Lira, S. M. (2016). Screening of bioactivities and toxicity of Cnidoscolus quercifolius Pohl. Evidence-Based Complementary and Alternative Medicine (Print), 2016. https://doi.org/10.4103/2221-1691.237077

Priac, A., Badot, P. M., \& Crini, G. (2017). Treated wastewater phytotoxicity assessment using Lactuca sativa: focus on germination and root elongation test parameters. Comptes Rendus Biologies, 340, 188-194. https://doi.org/10.1016/j.crvi.2017.01.002

Sacramento, E. B., Azevedo, C. D. A., Abreu, S. T., Borba, H. R., \& Lima, V. M. D. (2020). Evaluation of the cytotoxic and genotoxic potential of waters of the Paraíba do Sul River Basin-RJ through the Allium cepa test system. Revista Ambiente \& Água, 15. https://doi.org/10.4136/ambi-agua.2521

Sales, I. M. S., Barbosa, J. S., Santos, F. K. S., Silva, F. C. C., Ferreira, P. M. P., Sousa, J. M. C., \& Peron, A. P. (2017). Acute toxicity of grape, plum and orange synthetic food flavourings evaluated in vivo test systems. Food Technology and Biotechnology, 55, 131-137. https://doi.org/10.17113/fts.55.01.17.4770

Sanepar (2020). Paraná Sanitation Company. Retrieved January 1, 2021, form https://sanepar.com.br.

Santos, C.N., \& Carmo, B.C. (2020). The sustainability challenge in Cianorte's industrial laundries. Brazilian Journal of Development, 6, 83771-83785.

Schoenhals, M., \& Porto, A. E. (2013). Effluent treatment, water reuse and legislation applied in industrial textile laundry. Engenharia Ambiental: Pesquisa e Tecnologia, 10, 20-30. (in Portuguese). 
Research, Society and Development, v. 10, n. 8, e27610817336, 2021

(CC BY 4.0) | ISSN 2525-3409 | DOI: http://dx.doi.org/10.33448/rsd-v10i8.17336

Silva, M. S. D. (2020). Creation of APAs in the public supply source of Cianorte-PR: an alternative for the promotion of the sustainable use of the basin and the maintenance of the quality of the water resource. Dissertation, Universidade Tecnológica Federal do Paraná. (in Portuguese).

Silva, Y. G. A. E. S., Almeida, P. M., \& Peron, A. P. (2020). Irrigation water quality of a community garden complex in the State of Piauí, Northeastern Brazil. Water, Air, \& Soil Pollution, 231, 113. https://doi.org/10.1007/s11270-020-04486-1

Silva, T. D. S., Silva, A. P. S. E., de Almeida Santos, A., Ribeiro, K. G., Souza, D. C. D., Bueno, P. A. A., \& Peron, A. P. (2020). Cytotoxicity, Genotoxicity, and Toxicity of Plant Biostimulants Produced in Brazil: Subsidies for Determining Environmental Risk to Non-Target Species. Water, Air, \& Soil Pollution, 231, 1-8. https://doi.org/10.1007/s11270-020-04614-x

Silveira, G. L., Lima, M. G. F., Dos Reis, G. B., Palmieri, M. J., \& Andrade-Vieria, L. F. (2017). Toxic effects of environmental pollutants: Comparative investigation using Allium cepa L. and Lactuca sativa L. Chemosphere, 178, 359-367.

Souza, A.I. (2019). Logistical optimization of soy and corn storage units in the State of Paraná. Dissertation, State University of Western Paraná. (in Portuguese).

Souza, P. M. S., Sommaggio, L. R. D., Marin-Morales, M. A., Morales, A. R. (2020) PBAT biodegradable mulch films: Study of ecotoxicological impacts using Allium cepa, Lactuca sativa and HepG2/C3A cell culture. Chemosphere, 256, 126985. https://doi.org/10.1016/j.chemosphere.2020.126985

Tabrez, S., \& Ahmad, M. (2011). Oxidative stress-mediated genotoxicity of wastewaters collected from two different stations in northern India. Mutation Research/Genetic Toxicology and Environmental Mutagenesis, 726(1), 15-20. https://doi.org/10.1016/j.mrgentox.2011.07.012

Vasconcelos, J. F., Barbosa, J. E. L., Diniz, C. R., \& Ceballos, B. S. O. (2011). Cyanobacteria in reservoirs in the State of Paraíba: occurrence, toxicity and regulatory factors. Boletim da Sociedade Brasileira de Limnologia, 39, 1-20.

Yuet Ping, K., Darah, I., Yusuf, U. K., Yeng, C., \& Sasidharan, S. (2012). Genotoxicity of Euphorbia hirta: an Allium cepa assay. Molecules, 17, 7782-7791. https://doi.org/10.3390/molecules17077782

Vlček, V., \& Pohanka, M. (2018). Adsorption of copper in soil and its dependence on physical and chemical properties. Acta Universitatis Agriculturae et Silviculturae Mendelianae Brunensis, 66, 219-224. https://doi.org/10.11118/actaun201866010219

Zhao, L., Ortiz, C., Adeleye, A. S., Hu, Q., Zho, H., Huang, Y., \& Keller, A. A. (2016). Metabolomics to detect response of lettuce (Lactuca sativa) to Cu (OH) 2 nanopesticides: oxidative stress response and detoxification mechanisms. Environmental Science and Technology, 50, 9697-9707. https://doi.org/10.1021/acs.est.6b02763 